\title{
Adult Meningioma
}

National Cancer Institute

\section{Source}

National Cancer Institute. Adult Meningioma. NCI Thesaurus. Code C9093.

A mening ioma that occurs during adulthood. 